sier at alle pasienter med akutt, alvorlig pankreatitt skal ha bredsprektret antibiotika så tidlig som mulig, noe som ikke har vist seg å ha effekt på overlevelse i randomiserte studier.

Som en annerledes bok med en uvanlig didaktisk tilnærming er den et friskt pust og kan anbefales til studenter, turnusleger og unge som eldre kirurger. Boken bør leses med visse forbehold - verden er ikke alltid så svart-hvitt som Scheins sunne fornuft vil ha det til - men her er likevel mye nyttig.

Kjetil Søreide

Kirurgisk avdeling

Stavanger universitetssjukehus

\section{Godt om depresjon hos eldre}

Robert C. Baldwin

Depression in later life

118 s, tab, ill. Oxford: Oxford University Press, 2010. Pris GBP 6

ISBN 978-0-19-956901-4

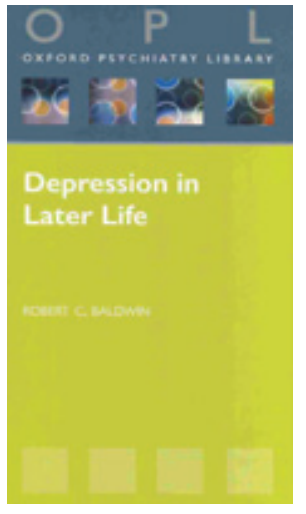

Dette er en ny lærebok i lommeformat $(10 \times 18$ $\mathrm{cm})$, utgitt i serien Oxford Psychiatry Library (OPL). Som hos de øvrige bøkene i serien er målgruppen klinikere, både allmennpraktikere og spesialister. Målet er å gi leserne en kortfattet, oppdatert

kunnskapsbasert fremstilling av dagens kunnskap om depresjoner hos eldre, om etiologi, klinisk presentasjon og ikke minst om hvilken behandling som virker. Forfatteren har solid erfaring og nok autoritet til også å meddele på hvilke områder kunnskapen er bristende, eller hvor bevisbyrden er for tynn til å formidle skråsikker kunnskap.

Boken er tradisjonelt oppbygd med ti kapitler som starter med epidemiologi og slutter med prognose og forebyggende tiltak. Et appendiks med nyttige evalueringsskalaer for depresjon er lagt til. Teksten er korthugget, lettlest og understøttes med illustrative tabeller, figurer og tekstbokser hvor man gjengir den viktigste informasjonen. Spesielt har man gitt kapitlet om behandling og behandlingsmuligheter stor plass. Leseren får på en nøktern måte informasjon om hvilke behandlingsmuligheter som finnes, og hvilke pasientkategorier som bør tilbys de ulike behandlingene.

Sammenhengen mellom depresjon som opptrer hos eldre, og komorbid somatisk sykdom er viet mye plass, og det er nødvendig. Forfatteren formidler også tydelig at depresjon hos eldre er en svært heterogen tilstand hvor det i mange tilfeller er vanskelig å peke på en utløsende faktor, ofte finnes det flere. Teorien om vaskulær depresjon, og den økende bevisbyrden for at det eksisterer en depresjonstype som er utløst på cerebrovaskulært grunnlag, har fått behørig plass. Man har også poengtert hvor viktig det er å tenke på selvmordsfare og å vurdere denne ved depresjon hos eldre. Det er faktisk ganske imponerende hvor mye god informasjon forfatteren har klart å kondensere på 118 «små» sider. Jeg kan anbefale boken til alle leger som behandler eldre pasienter. Spesielt vil allmennpraktikere finne mye god informasjon raskt, men også en psykiater vil ha glede av den oppdaterte kunnskapen som formidles.

\section{Knut Engedal}

Nasjonalt kompetansesenter for aldring og helse Geriatrisk avdeling

Oslo universitetssykehus, Ullevål

\section{Nyttig bidrag for å redusere mødredødelighet}

Verdens helseorganisasjon

WHO guidelines for the management of postpartum haemorrhage and retained placenta

59 s, tab, ill. Genève: WHO, 2009. Pris CHF 15 ISBN 978-92-4-159851-4

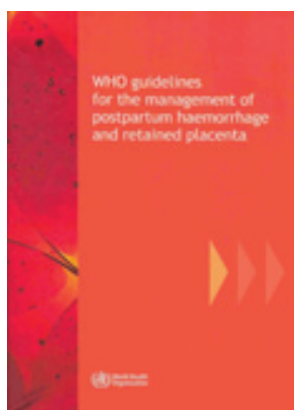

Ett av FNs millenniumsmål i år 2000 var å redusere mødremortaliteten $i$ verden med tre firedeler innen år 2015. For å bidra til arbeidet mot dette målet har WHO utgitt dette heftet i A4-format. Blødning post partum er globalt den viktigste årsaken til at kvinner dør i forbindelse med svangerskap og fødsel.

Heftet er ikke en lærebok, men en oppsummering av resultatene av litteratursøk om intervensjoner og behandlingsmåter som ble ansett som viktige av et internasjonalt panel av fag- og legfolk. Etter diskusjoner i et ekspertmøte i Genève i 2008 ble konklusjonene gradert etter evidens, hvor randomiserte undersøkelser selvsagt rangerer høyest. Det gir enkelte pussige resultater: Det er aldri utført, og vil heller aldri bli utført, randomiserte studier av aortakompresjon og bimanuell uteruskompresjon. For disse livreddende prosedyrene blir derfor kunnskapskvaliteten meget lav og anbefalingen svak.

Vedlagt heftet er det en oversiktlig plakat i A3-format med trinnvise behandlingstiltak ved post partum-blødning og retinert placenta. Anbefalingene er stort sett identiske med våre nasjonale retningslinjer i Norsk gynekologisk forenings Veileder i fødselshjelp 2008, som finnes tilgjengelig for alle på foreningens hjemmesider (1). Et liten forskjell: Misoprostol anbefales gitt sublingualt, ikke rektalt slik det er vanlig $i$ vårt land.

Heftet, som kan lastes ned gratis i PDFformat (2), gir en god oversikt over hvilken dokumentasjon som foreligger eller ikke foreligger for de forskjellige intervensjonene og behandlingsmetodene ved post partumblødning og ved fastsittende placenta. Det vil derfor være til nytte for kolleger som skal utarbeide retningslinjer for behandling av disse tilstandene, nasjonalt og lokalt på den enkelte avdelingen. En fyldig litteraturliste med 201 referanser er oppdatert til 2007. Andre kolleger, utdanningskandidater og spesialister i fødselshjelp vil ha begrenset utbytte av heftet, de bør heller lese $A$ textbook of postpartum hemorrhage (3).

\section{Kåre Augensen}

Kvinneklinikken

Haukeland universitetssykehus

\section{Litteratur}

1. Norsk gynekologisk forening. Veileder

i fødselshjelp 2008. www.legeforeningen.no/id/ 131068.0 (15.9.2010).

2. Verdens helseorganisasjon. WHO guidelines for the management of postpartum haemorrhage and retained placenta. http: //whqlibdoc.who.int/ publications/2009/9789241598514_eng.pdf (15.9.2010).

3. Børdahl PE. Nødvendig bok om post partum-blød ning. Anmeldelse av: B-Lynch C, Keith LG, Lalonde $A B$ et al, red. A textbook of postpartum hemorrhage. Tidsskr Nor Legeforen 2008; 128: 2357

\section{Viktig referanse for infeksjonstesting av blodgivere}

Verdens helseorganisasjon

Screening donated blood for transfusiontransmissible infections

Recommendations. $67 \mathrm{~s}$, tab, ill. Genève: WHO, 2010. Pris CHF 30

ISBN 978-92-4-154788-8

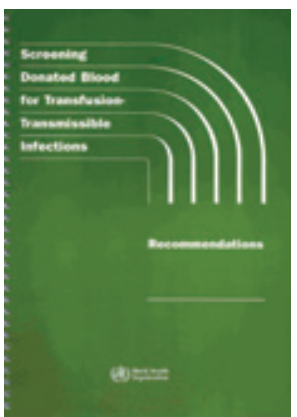

WHO arbeider kontinuerlig for å sikre kvaliteten i medlemslandenes helsetjeneste. En del av arbeidet består i å utgi anbefalinger til landenes helsemyndigheter. Anbefalingene søkes begrunnet i høy sakkunnskap og skal være grundig gjennomarbeidet. Listen over forfattere og medarbeidere i denne boken er impone- 
rende og borger for at dette gjelder også denne publikasjonen.

Målgruppen er først og fremst utviklingsland og andre land som ennå ikke har etablert en fullverdig transfusjonstjeneste. Skribentene henvender seg til alle som er involvert i oppbygging og drift av transfusjonstjenesten, fra helsepolitikere via administratorer til personell i blodbanker og mikrobiologiske laboratorier. Man gjennomgår prinsipper for utvikling av nasjonale programmer for vern mot smitte ved transfusjon, prinsipper for testanalyser, hvilke infeksjoner som alltid bør undersøkes, og hvilke som kan overlates til lokal avgjørelse, anbefalinger om karantenebestemmelser, administrasjon av blodgiverkorps og prinsipper for kvalitetssikring av testsystemene.

Forfatterne konsentrerer seg om testsystemer for infeksjonssykdommer og deres anvendelse i transfusjonstjenesten. De gir ikke en fullstendig oversikt over tiltak for smitteprofylakse. En slik oversikt ville ha krevd en langt mer omfangsrik publikasjon. Imidlertid fremhever man, meget prisverdig, betydningen av å basere all transfusjonstjeneste på frivillige, ubetalte blodgivere, og betydningen av at klinisk bruk av blod skjer på mest mulig rasjonelt grunnlag.

Transfusjonstjenesten i Norge oppfyller i stor grad anbefalingene $\mathrm{i}$ boken ved at vi følger EUs bloddirektiv, nedfelt i blodforskriften. Men Norge blir utfordret, bl.a. på at vi baserer oss på betalte blodgivere for å dekke vårt forbruk av plasmaprodukter, at vi ikke tester for syfilis annet enn ved nyregistrering av blodgivere, og at det er langt frem til vår transfusjonspraksis kan sies å ha tilfredsstillende rasjonell basis. Forfatterne understreker at en $100 \%$ infeksjonssikret transfusjonstjeneste er og blir en illusjon. Det er viktig at man gjør dette klart for våre helsepolitikere.

Denne utgivelsen vil være nyttig for kolleger som engasjerer seg i å utvikle transfusjonstjeneste $\mathrm{i}$ de primære målgruppelandene. Den vil også være en viktig referanse for arbeidet med smitteprofylakse i norsk transfusjonstjeneste. Boken må finnes hos sentrale helsemyndigheter, ved alle blodbanker med spesialist i immunologi og transfusjonsmedisin og ved mikrobiologiske avdelinger som utfører smittetesting av blodgivere.

\section{Hans Erik Heier}

Avdeling for immunologi og transfusjonsmedisin med Blodbanken i Oslo

Oslo universitetssykehus, Ullevål

\section{Rettsmedisin for ikke-medisinere}

Joseph Prahlow

Forensic pathology for police, death investigators, attorneys, and forensic scientists

632 s, tab, ill. Secaucus, NJ: Humana Press, 2010. Pris USD 199

ISBN 978-1-58829-975-8

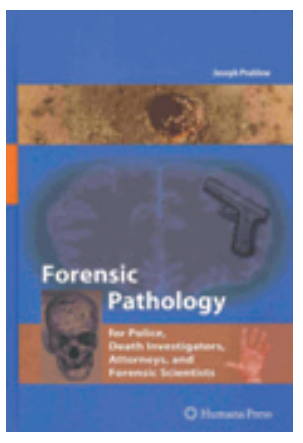

Rettsmedisin befinner seg i grenselandet mellom biomedisin og jus eller politifag. Det må fra begge sider være et visst overlapp av kunnskap; de medisinsk sakkyndige må forstå hvordan politi og rettsvesen fungerer, og politifolk og jurister må på samme måte vite litt om hvordan rettsmedisinere utøver sitt yrke. Denne boken skal være en innføring i rettspatologi for ikke-medisinere. Dessverre synes jeg ikke den er helt vellykket.

Boken er tredelt: Først er det en introduksjon til rettsmedisin som fag, i tillegg til en innføring $\mathrm{i}$ anatomi og fysiologi. Den neste hoveddelen er om arbeidsmåter og -oppgaver i rettspatologi (sakkyndig likundersøkelse, identifisering og dødstidspunktsbestemmelse). Den tredje delen, som utgjør omtrent to tredeler, er en systematisk gjennomgang av de ulike gruppene av dødsårsaker (naturlig død, stump vold, skuddskader osv.). Denne delen avslutter man med et ganske pussig «Diverse»-kapittel med de emnene som ikke passer inn andre steder, alfabetisk ordnet: aircraft crashes, allergic reactions, animal attacks osv.

Forfatteren forsøker å være systematisk og pedagogisk; hvert kapittel starter med et kort sammendrag og noen stikkord og avsluttes med henvisning til aktuelle bilder på medfølgende CD-ROM og et utvalg referanser, som stort sett er relevante og oppdaterte. Illustrasjonene er i svart-hvitt, mørke og med dårlig kontrast. Ikke alle bildene er like informative. CD-ROM-en med fargebilder er ikke helt komplett, men alle bildene kan også lastes ned fra forlagets nettsider. Det er overraskende at bildematerialet ikke er bedre gjennomarbeidet; noen av bildene er så små at detaljene knapt er synlige, mens andre tar unødvendig stor plass. Jeg synes også at detaljeringsgraden $i$ teksten varierer svært. For noen emner går forfatteren langt mer i dybden enn det som er hensiktsmessig for målgruppen, og på veien dit kan han hoppe over forklaringer som vil være nødvendige for en ikke-medisiner. I enkelte avsnitt er det også unødvendig mye medisinsk fagterminologi.

Det handler kun om den postmortale rettsmedisinen, og dette gjenspeiler vel den amerikanske organiseringen av faget. Norske politifolk og jurister som arbeider med personfarlig kriminalitet, har minst like stort behov for å vite noe om klinisk rettsmedisin, dvs. undersøkelse av levende personer. Rettsgenetikk er knapt nevnt, og det står kun en side om seksualrelaterte skader, omtalt i svært generelle ordelag.

Jeg mener at det finnes klart bedre bøker dersom politi og jurister i Norge ønsker seg en innføring i rettsmedisin. Den mest brukte norske er Laerebok i rettsmedisin (1). Den nyere danskspråklige Retsmedicin: nordisk loerebog er også et godt valg (2).

\section{Christian Lycke Ellingsen}

Avdeling for patologi

Stavanger universitetssjukehus

\section{Litteratur}

1. Rognum TO, red. Lærebok i rettsmedisin. Oslo: Gyldendal Akademisk, 2001

2. Thomsen JL, red. Retsmedicin: nordisk lærebog. 2. utg. København: FADL's Forlag, 2008.

\section{Oppdatert om malariabehandling}

Verdens helseorganisasjon

Guidelines for the treatment of malaria

2. utg. 194 s, tab, ill. Genève: WHO, 2010.

Pris CHF 20

ISBN 978-92-4-154792-5

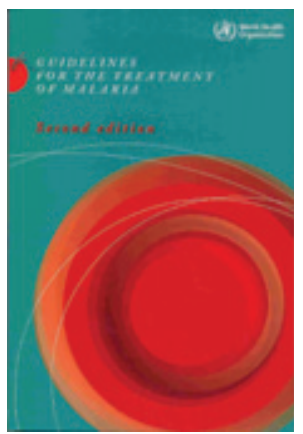

Dette er andre utgave av WHOs veileder om behandling av malaria. Målsettingen har vært å lage globale, kunnskapsbaserte retningslinjer. Bak disse retningslinjene står en bredt sammensatt inter-

nasjonal ekspertgruppe. Det redegjøres tillitvekkende for eventuelle interessekonflikter blant ekspertene. Kunnskapsgrunnlaget for nye råd er tydeligere angitt enn tidligere.

Retningslinjene starter i god WHO-tradisjon med et sammendrag. Deretter følger kapitler om sykdommen, epidemiologi, resistens og terapivalg i forskjellige situasjoner. Til slutt finner man ytterligere utdypning i form av flere vedlegg.

Som i forrige utgave er artemisininbasert kombinasjonsterapi (ACT) grunnsteinen i terapirådene. Da dokumentasjonen er manglende om sikkerhet i første trimester av svangerskapet, anbefales alternativ behandling tidlig i svangerskapet.

Rådene om behandling av reisende ved retur til ikke-endemisk område er av særlig 